\title{
Effective Participative Management: Does It Affect Trust Levels of Stakeholders in Schools?
}

\author{
Sello Mokoena \\ Department of Teacher Education, P.O. Box 392, University of South Africa, South Africa 0003 \\ Fax: 0866309490; E-mail: mokoesp@unisa.ac.za
}

KEYWORDS Decision-making. Trust. School Governing Bodies. Stakeholders. Democratic Governance

\begin{abstract}
This paper reports the findings of the small-scale study on the effectiveness of participative management (PM) as perceived by parents, learners, teachers, community leaders, members of the school governing body and the principal in one school in the Free State, a province of South Africa. Questionnaires were used to gather data and responses were tabulated using the SPSS. The questionnaires were completed by two hundred and eighty two (282) respondents out of three hundred and twenty (320) issued out, resulting in a response rate of $88.1 \%$. The study examined the correlation between the indicators of PM effectiveness and stakeholders' levels of trust. Findings show that the following indicators of PM effectiveness were significantly related to stakeholders' levels of trust: importance of sub-committee structures, satisfactory composition of the school governing body (SGB), adequacy of information for SGB decision-making, adequacy of time for doing SGB business, SGB influence on teaching and learning, and overall SGB functioning. It is suggested that school leaders wishing to enhance the levels of trust among the stakeholders should consider these indicators of PM effectiveness in carrying out their leadership duties and responsibilities.
\end{abstract}

\section{INTRODUCTION}

Traditionally, principals throughout the world have been the main decision-makers at school level. This situation has been particularly evident in a number of countries such as Australia, Canada, New Zealand, the United Kingdom, and parts of the United States of America (Imber et al. 1990; Griffin 1995; Jonston 1997). During the past 20 to 30 years there has been a major shift towards participative management (PM) in schools (Hart 1995; Mosoge and Van der Westhuizen 1998; Gultig and Butler 1999; Mabaso and Themane 2002; Bush and Heystek 2003a). These authors have called for greater participation in decision-making as a progressive way of making schools more democratic and more efficient.

In South Africa, for example, the new democratic government published a White Paper 2 on the organisation, governance and funding of schools. The aim was to help foster democratic school governance (by involving all of its stakeholders, including parents and learners, who are democratically elected). Democratic school governance is introduced by a structure that involves all the stakeholder groups in active and responsible roles to encourage tolerance, rational discussion and collective decision-making. From this White Paper emanated the 1996 South African Schools Act (Act 84 of 1996), which became operative at the beginning of 1997 and mandated that all public schools in South Africa must have democratically elected School Governing Bodies (SGBs) comprised of principals, educators, non-teaching staff, parents and learners, the latter applicable only in secondary schools. As a result, the nature and extent of school decisionmaking have changed. Decision-making at schools is now characterised by greater participation of all stakeholders. Parents, teachers, learners and non-teaching staff and stakeholders who are elected to serve on the school governing bodies become school governors. The term "stakeholders" is based on the assumption that certain groups and individuals have an interest, or a "stake", in the activities of an institution. According to Bush and Heystek (2003a), stakeholders are all those people who have a legitimate interest in the continuing effectiveness and success of an institution.

Although collaborative processes are increasingly called for as part of reform efforts in schools, these processes will not come about in an authentic form if the people involved do not trust one another. Principals who do not trust their teachers will not share authority and responsibility. Teachers who do not trust one another will not give over a measure of their autonomy in order to collaborate with others. School personnel who do not trust parents will guard against giving them a real voice in decision affecting the school.

Research has been conducted in schools operating under PM (Blase and Blase 2000; Crans- 
ton 2001; Bush and Heystek 2003b; Van Wyk 2004; Mncube 2007). However, little of this research has focused on schools in rural areas. Policy based on democratic principles has taken some time to filter down to rural schools. Therefore, the research which aimed at investigating the extent to which stakeholders in rural schools perceive and implement PM was timeous and necessary. This study attempts to build empirical evidence linking indicators of effective participative management to trust levels of stakeholders in rural schools. The study sought to investigate whether effective participative management affects trust levels of stakeholders in rural schools. More specifically the study aims to:

1. determine the stakeholders' perceptions of the operational effectiveness of PM

2. assess the levels of trust that stakeholders have in those who implement PM

3. find out whether the indicators of PM effectiveness are related to the stakeholders' levels of trust.

The paper posits that a significant factor in constructing a climate that supports collaboration in school is building an atmosphere of trust. This paper first briefly discusses how PM and building of trust contribute to better school or organisation outcomes. Next, the methodology and research design are described before the findings and the discussions are explained. Moreover, the respondents' perceptions on the effectiveness of PM were considered. The stakeholders' levels of trust in the practice of PM were also investigated. Finally, these perceptions on the effectiveness of PM were related to the levels of trust among the stakeholders before the conclusions were presented.

\section{ADOPTING PM FOR BETTER ORGANISATION OUTCOMES}

The shift to PM in the workplace is both inevitable and necessary (Gultig and Butler 1999; Mabaso and Themane 2002; Bush and Heystek 2003a). PM, as used in this study, refers to the involvement of various stakeholders in the governance of schools through their membership in a school governing body (SBG). However, SGB is but one example of PM. Practising participatory management has been long acknowledged as an essential ingredient in the quest for better schools. In characterising successful schools, researchers commonly list five school-level fac- tors, which include collaborative planning/collegial work and parental/community participation (Marzano 2003). Golarz and Golarz (1995: 3 ) assert that "high levels of parental involvement and support, collaborative collegial instructional planning, individual school autonomy and the resulting flexibility" are effective school characteristics that justify the implementation of participatory management. In fact, Cheng and Cheung (2003) have observed that efforts to enhance organisational effectiveness since 1990s have featured participative management. As Caldwell and Spinks (1992: 131) point out, securing a "synergy of communities" is the key to attainment of educational benefits. It should be noted, however, that attempts to involve stakeholders should be geared beyond mere participation but towards meaningful involvement (Waters et al. 2003).

Research findings show that allowing stakeholders to take part in decision-making yields salutary results. These results are job satisfaction (Robert 2000; Spence-Laschinger and Finegan 2004), perceived organisational support (Rhoades and Eisenberger 2002; Kim 2002; Lau and Lim 2002), the extension of stronger support to realise the goals (Gamage 1996), better decisions and greater efficiency (Hoy and Tarter 1993; Gamage 1996), organisational citizenship behaviour (Eisenberger et al. 1990), labour-management relations (Ospina and Yaroni 2003), job performance (Lau and Lim 2002; Ming 2004), employee satisfaction, motivation, morale and self-esteem (Hargreaves and Hopkins 1991), identifying and solving problems (Blasé and Blasé 2001), establishment of strong networks among the members (Hargreaves 2001), open communication (Blase and Blase 2001; Saunders and Thornhill 2003), and supportive and collegial behaviour of the leader (Hoy and Tarter 1993). Moreover, researchers claim that better decisions and greater efficiency are reached since issues are discussed extensively through open communication among people with varying viewpoints involved in participative set-ups (Hargreaves and Hopkins 1991; Beyerlein et al. 2003; Wong 2003).

Another noteworthy impact of PM is that participants tend to have a sense of ownership of change initiatives and eventually offer stronger support to realise the goals of such efforts (Gamage et al. 1996). Implementing participative management practices is also known to yield the 
following benefits: administrators cannot easily manipulate people, teachers are given a sense of control over their own working lives and power inequities are balanced (Harchar and Hyle 1996), and, finally, additional resources become available to the organisation (Lienhart and Willert 2002).

Then how can a person be identified as a participatory manager? A study conducted by Larry Greiner in the early 1970s rated thirty-nine leadership characteristics based on what 157 managers thought of PM. Managers chose ten characteristics they felt were representative of a participatory manager. Ranked in order, from the most to the least participative, the characteristics are:

1. Gives subordinates a share in decisionmaking.

2. Keeps subordinates informed of the true situation, good or bad, under all circumstances.

3. Stays aware of the state of the organisation's morale and does everything possible to make it high.

4. Is easily approachable.

5. Counsels, trains and develops subordinates.

6. Communicates effectively with subordinates.

7. Shows thoughtfulness and consideration of others.

8. Is willing to make changes in ways of doing things.

9. Is willing to support subordinates even when they make mistakes.

10. Expresses appreciation when a subordinate does a good job (Albanese 1975).

\section{Barriers to Participatory Management}

Barriers to PM are usually of three types: controllable, uncontrollable and capable of being influenced. Controllable factors may include inadequate time with employees as well as lack of training and interest on the part of employees. Uncontrollable factors may be the reputation of the department, structure of media services, and the area of service within the organisation. Barriers that may be influenced may be a lack of knowledge in PM by a supervisor, an organisational climate that is not conducive to PM, and a supervisor who is unwilling to spend the time to practice PM (Shagoli et al. 2010).

\section{Trust in Organisations}

Apart from PM, enhancing levels of trust within an organisation bestows a variety of benefits (Blase and Blase 2001; Tschannen-Moran 2001). "Trust" as used in this paper refers to someone who feels confident and assured in allowing something to be in the care or control of another. Bryk and Schneider (2002) argue that allowing relational trust to grow in a school community triggers the effective interplay between the various factors towards academic productivity. In fostering trust, certain aspects of participatory practices have been found to be essential. These practices are open communication (Hoffman et al. 1994; Blase and Blase 2001; Saunders and Thornhill 2003), and the supportive and collegial behaviour of the leader (Tschannen-Moran and Hoy 1998; Lichtenstein 2000; Waters et al. 2003).

A variety of benefits can be derived by organisations that can foster an atmosphere of trust (Tschannen-Moran 2001). To stress the value of trust in schools, Blasé and Blasé (2001: 23) wrote: "The reward of a trusting environment is immeasurable, yet the price of lack of trust is dear." The authors add that when there is trust, people are able to work together in identifying and solving problems. Siegall and Worth (2001) report that greater the trust in the administration, the more positive work outcomes among faculty members. In high-trust groups, the socially generated uncertainty is minimal and problem solving is more effective (Tschannen-Moran 2001). Hargreaves (2001) argues that high levels of trust hasten the establishment of strong networks and collaborative relations among the members and stakeholders in a school rich in social capital. As Coleman (1988: 101) notes, "a group within which there is extensive trust is able to accomplish much more than a comparable group without trustworthiness and trust".

Successful implementation of school based management (SBM) or any form of school renewal is hinged on trust (Daniels 1996; Spilman 1996). Gamage (1998) states that in schools with open climates, trust and confidence between the teachers and students or the teachers and parents in schools promote unity in the school community and the attainment of greater school effectiveness. When trust and collaborative spirit pervade at faculty meetings, collegiality is fostered 
(Edwards et al. 2002). Additionally, TschannenMoran (2001) argues that people who have stronger trust in the organisation's decision makers tend to be more satisfied with their level of participation.

There is evidence that trust contributes to organisational effectiveness in schools. Unline et al. (1998) revealed the link between trust and school effectiveness by demonstrating that the expressive factors of trust and a healthy school climate made as great contribution to school effectiveness as the more instrumental factors of standardised student scores. In addition, teachers' trust in their principal as well as in their colleagues has been linked to the effectiveness of school (Tarter et al. 1995). Trust in colleagues has been found to have a significant impact on student achievement in elementary schools (Goddard et al.2000). The climate of the school can be one that cultivates trust or that makes trust difficult to foster. Openness in the school climate and healthy interpersonal relationships tend to foster a climate of trust (Tarter et al. 1995). Healthy interpersonal relationships have been related to participation in decision making in schools (Sabo et al.1996).

Similarly, a study of trust-effectiveness patterns in 79 American Midwestern schools concluded that high trust among parents and teachers in a high socio-economic status school leads to a positive belief in teacher efficacy, facilitating effective school structures and high academic performance (Forsyth et al. 2006). Forsyth and colleagues (2006) also found that parents' trust influences academic performance more than the teachers' trust.

Indeed, it can be concluded that fostering an atmosphere of trust pays significant dividends for schools. Improved effectiveness, communication, organisational citizenship and student achievement are worthy ends. An additional benefit may be the ability to create more genuine forms of collaboration between the principal and teachers, between teacher colleagues, and between parents and the school. Therefore, trust brings about salient benefits to the organisation in the form of better performance outcomes.

The next section of this article briefly discusses the methodology and design, context of the study, the characteristics of the participants and the derivation of the measurement instruments used.

\section{METHODOLOGY AND RESEARCH DESIGN}

The study employed the correlational research design. In correlational studies, the basic aim is to measure and describe a relationship between two variables by determining the magnitude and direction of such a relationship, if any exists (Pagano 1998; Gravetter and Wallnau 2004). The relationships do not necessary suggest causation.

\section{The Context of the Study}

Research was conducted in a public school located in a rural village in the Free State, a province of South Africa. The majority of the learners attending the school come from a poor socioeconomic background. The local community consists of a few working-class families and unemployment rate in the area is very high. Sixty to seventy per cent of learners qualify for fee exemptions as parents are unable to pay the school fees of R150 per annum. The school enrols 300 learners per year and classrooms are inadequate, and as many as 60 learners sometimes have to be cramped into a single classroom. The school has established a number of formal structures that enable teachers, learners and parents to become involved in the school and participate in its decision-making. There is a strong sense that these structures create considerable opportunities for involving other stakeholders. These structures include:

- The School Governing Body: This structure is the strategic planning and monitoring body whose members are elected by teachers, learners and parents. It holds considerable responsibility for setting the broad direction of the school, allocating resources to support priorities and monitoring progress.

- $\quad$ The School Management Team (SMT): The SMT comprises the principal, deputy principal and heads of department. This team manages day-to-day operational matters.

- The Class Parent Forum: This body comprises parent representatives for each class. Members serving on the forum meet fortnightly with the principal or one of the deputy principals. The purpose is to provide an opportunity to exchange ideas and share information in an informal setting.

- The Learning Areas Management Committee: The heads of department ser- 
ve on this committee which is assigned the responsibility to develop an annual operational plan (including a budget) for the different departments. The school governing body approves these plans.

- The Learners' Representative Council: This body represents learners on the school governing body.

- The Curriculum Development and Time Table Committee: This committee comprises teachers and heads of department and is responsible for compiling a time table and reviewing the curriculum.

The Free State Education Department regards this school as one of the better rural schools in the region. This is one of the reasons why the school was selected for this study.

\section{Participants}

Respondents in this study came from one public school located in the rural area of the Free State. By involving only one school, the study is not meant to be representative of the entire population but aims to explore perceptions of the respondents on the subject being pursued. Again, the purpose of this study is to provide in detail all that goes on in that school that has been selected. The research study targeted all the stakeholders, namely the school principal, parents, teachers, school governing body, learners and the community leaders. Random sampling was conducted to select a representative sample of learners across all the grades in the school. Teachers were purposefully selected taken into account their work experience at the school. A random sampling was also conducted to select a representative sample of parents who have children attending at the selected school. All other stakeholders were selected through their representation on the school governing body (SGB).

\section{The Data-Collection Instruments}

The study was descriptive, involving quantitative data collection and analysis. A questionnaire was used for data collection. In all, three hundred and twenty (320) questionnaires were distributed for data collection. The questionnaire consisted of two parts. The first part was designed to elicit data about the location and democratic structures in place in the school and contained closed questions (multiple-choice or yes/no questions). The second part of the questionnaire was designed to elicit data following the aim of the study and guiding research questions. The next section discusses design of the questionnaire.

\section{The Design of the Questionnaire Used for Data Collection}

A questionnaire, originally developed by Gamage (1996c), was used with appropriate adaptations to determine the respondents' perceptions of the operational effectiveness of PM. The 23-item questionnaire included items on the respondents' personal information, the SGB decision-making processes, use of sub-committees and the operation of the SGB. The questions were mostly of the multiple-choice Likert-type with open-ended questions in relevant areas.

Another questionnaire was designed to assess the levels of stakeholders' trust in the practice of PM. An existing instrument for measuring trust developed by Hoy and Kupersmith (1985) was used with appropriate adaptations to suit the needs of this research. A six-point Likert response format $(1=$ strongly disagree, $2=$ disagree, $3=$ slightly disagree, $4=$ slightly agree, $5=$ agree, and $6=$ strongly agree) was used.

Considering that the items used were taken from questionnaires previously validated in earlier research studies, no attempt was made to undertake a pilot run of the questionnaire used in this research. It was assumed that the questionnaire items used constitute a valid tool for measuring the variables under study.

\section{FINDINGS AND DISCUSSION}

The questionnaire was completed by two hundred and eighty two (282) respondents out of three hundred and twenty (320) issued out, resulting in a response rate of $88.1 \%$. The next sections focus on the findings based on the research questions.

The next section discusses the findings of the first question of the aim of the study. The first inquiry was an attempt to determine the stakeholders' perceptions of the operational effectiveness of PM.

\section{First Inquiry: Perceptions of the Respondents on the Operational Effectiveness of PM}

The first research question focused on the perceptions of the research respondents on the 
operational effectiveness of PM. Indicators of PM effectiveness included composition of the SGB, importance of the sub-committee structure, power and authority of the SGB, information for SGB to decisions, availability of time for SGB business, SGB influence on teaching and learning and overall functioning of the SGB. The indicators of effective PM are discussed below together with the findings.

The next sections discuss the results of the indicators of PM effectiveness as perceived by participants.

\section{Composition of the School Governing Body}

Table 1 shows how the respondents viewed the composition of the SGB. The results show that almost $92.5 \%$ of the respondents viewed the composition of the SGB as democratic and representative of all the stakeholders (parents, teachers, learners, and community leaders). It is interesting to note that only $0.7 \%$ of the participants found the composition of the SGB to be unsatisfactory. The calculated average mean score indicates 3.6132, where $5=$ excellent and $1=$ unsatisfactory.

Table 1: Composition of the school governing body (SGB)

\begin{tabular}{lrrrr}
\hline Response rate & Value & Frequency & $\begin{array}{l}\text { Percent- Cumu- } \\
\text { age }\end{array}$ & $\begin{array}{l}\text { Cutive } \\
\text { percent- } \\
\text { age }\end{array}$ \\
\hline No response & 0 & 19 & 6.7 & 6.7 \\
Unsatisfactory & 1 & 2 & 0.7 & 7.4 \\
Poor & 2 & 0 & 0 & 7.4 \\
Good & 3 & 124 & 43.9 & 51.3 \\
Very good & 4 & 105 & 37.2 & 88.5 \\
Excellent & 5 & 32 & 11.4 & 100.0 \\
\hline Total & \multicolumn{5}{c}{100.0} \\
\hline Mean: & 3.6132 &
\end{tabular}

\section{The Importance of the Sub-Committee Structures}

Table 2 presents the perceptions of the participants on the importance of sub-committee structures. Again, 90.8\% were highly satisfied with the importance of the sub-committee structures (rating it as good, very good and excellent) whereas only $1.4 \%$ found it to be unsatisfactory. This result is similar to the findings by Gamage and colleagues (Gamage et al. 1996) in the Victorian effective schools, which is a virtual en- dorsement of the committee structure as a very useful feature of PM. The authors argue that the existence of sub-committee facilitates the exploration of alternative solutions, saves SGB time and enables the wider participation of stakeholder groups. The discussion that went on under the context of the study demonstrated that the school had established few committees and if used appropriately will benefit the school.

Table 2: The importance of the sub-committee structures

\begin{tabular}{lrrrr}
\hline Response rate & Value & Frequency & $\begin{array}{l}\text { Percent- Cumu- } \\
\text { age }\end{array}$ & $\begin{array}{l}\text { Cutive } \\
\text { percent- } \\
\text { age }\end{array}$ \\
\hline No response & 0 & 22 & 7.8 & 7.8 \\
Unsatisfactory & 1 & 4 & 1.4 & 9.2 \\
Poor & 2 & 0 & 0 & 9.2 \\
Good & 3 & 120 & 42.5 & 51.7 \\
Very good & 4 & 100 & 35.5 & 87.2 \\
Excellent & 5 & 36 & 12.8 & 100.0 \\
\hline Total & \multicolumn{5}{c}{100.0} \\
\hline Mean: & 282 & 3.6154
\end{tabular}

\section{Power and Authority Vested in the SGB}

Table 3 shows that adequate power and authority were available to the SGB as claimed by $85.1 \%$ of respondents, with a mean of 2.0077 in a scale of 1 - 3 with 3 indicating too much power. Too much power and authority were found to be vested in the SGB by $4.6 \%$ of participants, while only $2.5 \%$ claimed that the SGB' power and authority was not adequate.

Table 3: Power and authority vested in the SGB

\begin{tabular}{lcrrr}
\hline Response rate & Value & Frequency & $\begin{array}{l}\text { Percent- Cumu- } \\
\text { age }\end{array}$ & $\begin{array}{l}\text { Cutive } \\
\text { percent- } \\
\text { age }\end{array}$ \\
\hline No response & 0 & 22 & 7.8 & 7.8 \\
Not adequate & 1 & 7 & 2.5 & 10.3 \\
Adequate & 2 & 240 & 85.1 & 95.4 \\
Too much & 3 & 13 & 4.6 & 100 \\
\hline Total & 282 & 100.0 \\
Mean: & 2.0077
\end{tabular}

This suggests that the school principal was willing to empower others in the pursuit of better output. Considering the history of school principals possessing high levels of power and authority prior the introduction of the South Afri- 
can Schools Act (SASA), this finding implies that the school principal on his own free will shared the power and authority. However, this trend contradicts the notion that empowering the formerly powerless is difficult because everyone wished to be in control (Parish and Aquila 1996).

Table 4 shows that $91.0 \%$ of the participants were highly satisfied with the amount and quality of information provided for decision-making by rating their responses as excellent, very good, and good as indicated in the table. This finding suggests that information was made available to the members of the SGB before they deliberated on courses of action to be taken in improving the school. Indeed, keeping communication channels open is an important factor for the success of school councils (Gamage and Pang 2003). Considering that school principals are the usual gatekeepers of information flow, it can be said that school principal involved in the study was willing to share vital information with others, particularly with the members of the SGB. This transparency is a positive contributor in encouraging stakeholders' involvement in school level policy-making, which the study was investigating.

Table 4: Availability of sufficient information to enable SGB to make effective decisions

\begin{tabular}{lrrrr}
\hline Response rate & Value & Frequency & $\begin{array}{l}\text { Percent- Cumu- } \\
\text { age }\end{array}$ & $\begin{array}{l}\text { lative } \\
\text { percent- } \\
\text { age }\end{array}$ \\
\hline No response & 0 & 23 & 8.2 & 8.2 \\
Unsatisfactory & 1 & 1 & 0.4 & 8.6 \\
Poor & 2 & 1 & 0.4 & 9.0 \\
Good & 3 & 125 & 44.3 & 53.3 \\
Very good & 4 & 100 & 35.4 & 88.7 \\
Excellent & 5 & 32 & 11.3 & 100.0 \\
\hline Total & 282 & 100.0 \\
\hline Mean: & 3.6023 &
\end{tabular}

\section{Availability of Time for SGB Business Matters}

As indicated in Table 5, 73\% of the participants reported that there was adequate time allocated for SGB to do school related business matters; $4.9 \%$ indicated that time was more than adequate; $8.5 \%$ barely adequate; and $6.0 \%$ inadequate with a mean score of 2.8314. This finding reveals that, generally, the SGB was able to devote sufficient time for discussing problems and issues that were submitted for their consideration.

Table 5: Availability of time for SGB business matters

\begin{tabular}{|c|c|c|c|c|}
\hline Response rate & Value & Frequency & $\begin{array}{l}\text { Percent- } \\
\text { age }\end{array}$ & $\begin{array}{l}\text { Cumu- } \\
\text { lative } \\
\text { percent- } \\
\text { age }\end{array}$ \\
\hline No response & 0 & 21 & 7.4 & 7.4 \\
\hline Inadequate & 1 & 17 & 6.0 & 13.4 \\
\hline Barely adequate & 2 & 24 & 8.5 & 21.9 \\
\hline Adequate & 3 & 206 & 73.0 & 94.9 \\
\hline $\begin{array}{l}\text { More than } \\
\text { adequate }\end{array}$ & 4 & 14 & 4.9 & 100 \\
\hline Total & & 282 & 100.0 & \\
\hline Mean: & & 2.8314 & & \\
\hline
\end{tabular}

\section{Perceptions on the Influence of the SGB on Teaching and Learning}

Table 6 shows the influence of the SGB on the teaching/learning situation in the school as perceived by the respondents. The results suggest that $49.6 \%$ acknowledged that it has improved significantly; $34.8 \%$ claimed that it has improved a little; $7 \%$ said that it was insignificant whereas only $1.4 \%$ felt that the SGB has not made any difference. The mean score of 4.4351 suggests that the SGB influence varied from significant to little. Indeed, the majority recognised that their efforts contributed to the improvements in teaching and learning. Yet, we need to be cautious since it is possible that the respondents might have over-estimated their own contributions. However, it is important to note that the SGB has contributed to the issues concerning teaching/learning.

Table 6: Perceptions on the influence of the SGB on teaching and learning

\begin{tabular}{lrrrr}
\hline Response rate & Value & Frequency & \multicolumn{2}{c}{$\begin{array}{l}\text { Percent-Cumu- } \\
\text { age }\end{array}$} \\
& & & \multicolumn{2}{c}{$\begin{array}{l}\text { lative } \\
\text { percent- } \\
\text { age }\end{array}$} \\
\hline No response & 0 & 20 & 7.1 & 7.1 \\
It has deteriorated & 1 & 0 & 0 & 7.1 \\
$\begin{array}{l}\text { It has made no } \\
\quad \text { difference }\end{array}$ & 2 & 4 & 1.4 & 8.5 \\
$\begin{array}{l}\text { It is insignificant } \\
\text { It has improved a }\end{array}$ & 3 & 20 & 7.0 & 15.5 \\
$\quad$ little & 98 & 34.8 & 50.3 \\
$\begin{array}{l}\text { It has improved } \\
\quad \text { significantly }\end{array}$ & 5 & 140 & 49.6 & 100.0 \\
\hline Total & \multicolumn{5}{c}{100.0} \\
\hline Mean: & 4.4351 & & \\
\hline
\end{tabular}




\section{Perceptions of Participants on the Overall Functioning of the SGB"}

Table 7 shows how the participants perceived the overall functioning of the SGB. It is interesting to note that $90.2 \%$ of the participants were satisfied with the overall functioning of the SGB on the basis of their evaluation of the performances as good, very good and excellent whereas $1.5 \%$ considered the overall functioning as either poor or unsatisfactory. The mean score of 3.5637 shows this high degree of satisfaction. In this context, the experimental study affirms that the stakeholder participation is a very useful tool in leading and managing schools.

Table 7: Perceptions of participants on the overall functioning of the SGB

\begin{tabular}{|c|c|c|c|c|}
\hline Response rate & Value & Frequency & $\begin{array}{l}\text { Percent- } \\
\text { age }\end{array}$ & $\begin{array}{l}\text { Cumu- } \\
\text { lative } \\
\text { percent- } \\
\text { age }\end{array}$ \\
\hline No response & 0 & 23 & 8.2 & 8.2 \\
\hline Unsatisfactory & 1 & 1 & 0.4 & 8.6 \\
\hline Poor & 2 & 3 & 1.1 & 9.7 \\
\hline Good & 3 & 130 & 46.0 & 55.7 \\
\hline Very good & 4 & 93 & 32.9 & 88.6 \\
\hline Excellent & 5 & 32 & 11.3 & 100.0 \\
\hline Total & & 282 & 100.0 & \\
\hline
\end{tabular}

The next section addresses the second part of the aim of this study. The second question was an attempt to assess the levels of trust that stakeholders have in the practice of PM.

\section{Second Inquiry: The Stakeholders' Levels of Trust}

The second research question sought to determine the levels of trust of the stakeholders in the implementation PM. The trust levels of the 282 respondents yielded a mean score and standard deviation equivalent to $(\mathrm{M}=5.39, \mathrm{SD}=$ $.575)$. In the scale ranging from $1-6$ with 6 indicating the highest level, it suggests that the stakeholders had a high level of trust on the people who are entrusted to implement PM. This result suggests that the stakeholders were inclined to put themselves in the care of those who are assigned to lead the school. In other words, the stakeholders were confident that the school leaders had the general welfare of everyone in the school at heart.
In terms of the levels of trust of the specific stakeholders, the mean and standard deviations were $(\mathrm{M}=5.45, \mathrm{SD}=.553)$ for teachers; $(\mathrm{M}=$ $5.41, \mathrm{SD}=.601)$ for learners; $(\mathrm{M}=5.34, \mathrm{SD}=$ $.624)$ for parents; and $(\mathrm{M}=5.35, \mathrm{SD}=.507)$ for community leaders. The stakeholders' levels of trust were not significantly different on the basis of their constituency. The F value for level of trust and constituency was .244, $\mathrm{p}=.943$. This result indicates that the building of trust among the stakeholders in the school was not related to the constituency each stakeholder represented. In other words, regardless of the type of stakeholder involved in participatory management, trust may either be increased or decreased on the basis of their individual performance.

The last inquiry of this study was an attempt to find out whether the indicators of PM effectiveness are related to the stakeholders' levels of trust. The next section discusses the findings.

\section{Third Inquiry: PM Effectiveness and Levels of Trust}

The third research question focused on the relationships between the indicators of PM effectiveness and the stakeholders' levels of trust. The number of respondents $(\mathrm{N})$ in Table 8 was determined by adding frequencies to all the response rate categories excluding frequencies to no response category. Table 8 shows that the respondents' levels of trust were significantly correlated to their perceptions on the composition of the SGB, the importance of the sub-committee structure, the adequacy of information for SGB to make effective decision, the time available for SGB to deal with school-related business matters, the influence of the SGB on teaching and learning, and the overall functioning of the SGB. Only their perception on the power and authority granted to the SGB did not yield a significant correlation with the levels of trust.

The stakeholders who indicated higher levels of trust were moderately satisfied with the composition of the SGB and perceived the overall SGB functioning to be effective. To a lesser degree, trust levels were also found to be associated with the stakeholders' perceptions of the importance of the sub-committee structure and adequacy of information and time for doing SGB business. There was also a weak correlation between the level of trust and the stakeholders' perceptions of the SGB's influence on teaching and learning. 
Table 8: The correlation between the respondents' levels of trust and their perceptions of the effectiveness of implementing PM

\begin{tabular}{|c|c|c|c|}
\hline \multirow[t]{2}{*}{ Indicators of PM effectiveness } & \multicolumn{3}{|c|}{ Trust levels } \\
\hline & $N$ & $\begin{array}{l}\text { Pearson } \\
\text { correla- } \\
\text { tion }\end{array}$ & $\begin{array}{l}\text { Signifi- } \\
\text { cance } \\
(2- \\
\text { tailed) }\end{array}$ \\
\hline Composition of the SGB & 263 & $.315^{* *}$ & .000 \\
\hline $\begin{array}{l}\text { Importance of sub-committee } \\
\text { structure }\end{array}$ & 260 & $.268^{* *}$ & .000 \\
\hline Power and authority of SGB & 260 & -.117 & .059 \\
\hline $\begin{array}{l}\text { Information for SGB decision- } \\
\text { making }\end{array}$ & 259 & $.276^{* *}$ & .000 \\
\hline $\begin{array}{l}\text { Availability of time for SGB } \\
\text { business }\end{array}$ & 261 & $.248^{* *}$ & .000 \\
\hline $\begin{array}{l}\text { SGB's influence on teaching } \\
\text { and learning }\end{array}$ & 262 & $.191^{* *}$ & .002 \\
\hline Overall SGB functioning & 259 & $.325^{* * *}$ & .000 \\
\hline
\end{tabular}

${ }^{* *}$ Correlation is significant at the 0.01 level (2-tailed)

This shows that respondents who reported favourable perceptions of the composition of the SGB, importance of the sub-committee structure, adequacy of information for SGB decision making, availability of time for SGB business, the SGB's influence on teaching and learning, and overall SGB functioning were more likely to report higher levels of trust while implementing PM. This suggests that indicators of effective PM can directly or indirectly affect the stakeholders' level of trust.

Previous research studies appear to show results congruent with the findings of this study. These previous research results confirm that trust is enhanced when leadership behaviour is characterised as supportive (Tarter and Hoy 1998; Tarter et al. 1989) and collegial (Tarter and Hoy 1998; Tschannen-Moran and Hoy 1998; Blase and Blase 2001). Likewise, researchers have declared that open communication fosters trust (Blase and Blase 2001; Saunders and Thornhill 2003). Sharing of information, using committees, providing adequate time for doing SGB business, enabling SGB to be composed of members from diverse stakeholders are examples of supportive and collegial leadership behaviours.

That the perceived power and authority given to the SGB did not significantly relate to the stakeholders' levels of trust is something future implementers of PM should consider. Perhaps, among the factors considered in this research, enabling stakeholders to feel that they possess the power and authority to influence school decisions is the most difficult to accomplish. An- other implication could be that the stakeholders were still aware that in the PM model implemented, school principals had the final authority to make decisions.

\section{CONCLUSION}

The results indicate that the stakeholders found the implementation of PM through the SGB to be effective. The effectiveness of implementing PM through the SGB as perceived by the participants reinforces the finding that their levels of trust were also high. Indeed, many factors affect the fostering of trust in the school. However, this study has shown that, to some degree, adequacy of time for SGB business, satisfaction with the composition of the SGB, appreciation of the role of committees, sharing of information, perceived influence on teaching and learning, and overall satisfaction with the operation of the SGB significantly related to the trust levels among the stakeholders.

It is therefore suggested that school leaders wishing to enhance the levels of trust among the stakeholders in their schools should endeavour to achieve a balanced representation in the SGB, utilise elected committees appropriately, share more information with other stakeholders, provide adequate time for doing SGB business, and focus on teaching and learning to make the overall functioning of SGB highly effective.

\section{REFERENCES}

Albanese R 1975. Management: Towards Accountability for Performance. Homewood, Ill.: Richard D. Irwin, Inc.

Anderson GL 1998. Toward authentic participation: Deconstructing the discourses of participatory reforms in education. American Educational Research Journal, 35(4): 571-603.

Beyerlein MM, Freedman, S, McGee C, Moran L 2003. Beyond Teams: Building the Collaborative Organization. San Francisco, California: Jossey-Bass/ Pfeiffer.

Blase J, Blase J 2000. Principals' perspectives on shared governance leadership. Journal of School Leadership, 10(1): 9-39.

Blase J, Blase J 2001. Empowering Teachers: What Successful Principals Do? $2^{\text {nd }}$ Edition. Thousand Oaks, California: Corwin Press, Inc.

Bryk AS, Schneider B 2002. Trust in Schools: A Core Resource for Improvement. New York: Russell Sage Foundation.

Bush T, Heystek J 2003a. School governance in South Africa. Compare, 33(2): 127-138.

Bush T, Heystek J 2003b. School governance in the new South Africa. Comapre, 33(2): 127-138. 
Caldwell BJ, Spinks JM 1992. Leading the Self-managing School. London: The Falmer Press.

Chapman JD, Boyd WL 1986. Decentralization, devolution, and the school principal: Australian lessons on state-wide educational reform. Educational Administration Quarterly, 22(4): 28-58.

Cheng YC, Cheung WM 2003. Profiles of multi-level selfmanagement in schools. The International Journal of Educational Management, 17(3): 100-115.

Coleman JS 1988. Social capital and the creation of human capital. American Journal of Sociology, 94: 95-120.

Cranston NC 2001. Collaborative decision-making and school-based management: Challenges, rhetoric and reality. Journal of Educational Enquiry, 2(2): 1-22.

Daniels H 1996. The best practice project: Building parent partnerships in Chicago. Educational Leadership, 53(7): 38-43.

Edwards JL, Green KE, Lyons CA 2002. Personal empowerment, efficacy, and environmental characteristics. Journal of Educational Administration, 40(1): $67-86$

Eisenberger R, Fasolo P, Davis-LaMastro V 1990. Perceived organizational support and employee diligence, commitment, and innovation. Journal of Applied Psychology, 75(1): 51-59.

Forsyth PB, Barnes LLB, Adams CM 2006. Trusteffectiveness patterns in schools. Journal of Educational Administration, 44(2): 122-141.

Gamage DT 1996. School-based Management: Theory, Research and Practice. Colombo: Karunaratne and Sons Ltd.

Gamage DT 1996c. School-based Management: Theory, Research and Practice. Colombo: Karunaratne and Sons Ltd.

Gamage DT 1998. How did school and community partnerships result in more effective schools in Australia? Perspectives in Education, 14(1): 47-59.

Gamage DT, Pang NS 2003. Leadership and Management in Education: Developing Essential Skills and Competencies. Hong Kong: The Chinese University Press.

Gamage DT, Sipple P, Partridge P 1996. Research on school-based management in Victoria. Journal of Educational Administration, 34(1): 24-40.

Goddard RD, Tschannen-Moran M, Hoy WK 2000. Teacher Trust in Students and Parents: A Multilevel Examination of the Distribution and Effects of Teacher Trust in Urban Elementary Schools. Working Paper. University of Michigan, Ann Arbor, MI.

Golarz RJ, Golarz MJ 1995. The Power of Participation: Improving Schools in a Democratic Society. Illinois: Research Press.

Gravetter FJ, Wallnau LB 2004. Statistics for the Behavioural Sciences. $6^{\text {th }}$ Edition. Australia: Thomson/Wadsworth.

Griffin GA 1995. Influences of shared decision-making on school and classroom activity. The Elementary School Journal, 96: 29-45.

Gulting J, Butler, D 1999. Creating People-centred Schools: School Organisation and Change in South Africa. London: Oxford University Press.

Harchar RL, Hyle A 1996. Collaborative power: A grounded theory of administrative instructional leadership in the elementary school. Journal of Educational Administration, 34(3): 15-29.

Hargreaves DH 2001. A capital theory of school effective- ness and improvement British. Educational Research Journal, 27(4): 487-503.

Hargreaves DH, Hopkins D 1991. The Empowered School: The Management and Practice of Development Planning. London: Cassell Educational Limited.

Hart AW 1995. Re-conceiving school leadership. Elementary School Journal, 96(1): 9-28.

Hoffman J, Sabo D, Bliss J, Hoy W 1994. Building a culture of trust. Journal of School Leadership, 4: 484-501

Hoy WK, Kupersmith WJ 1985. The meaning and measure of faculty trust. Educational and Psychological Research, 5(1): 1-10.

Hoy WK, Tarter CJ 1993. A normative theory of participative decision making in schools. Journal of Educational Administration, 31(3): 4-19.

Imber M, Neidt WA, Reyes P 1990. Factors that contributing to teacher satisfaction with participative decision-making. Journal of Research and Development in Education, 23(4): 216-225.

Jonston C 1997. Leadership and the Learning Organisation in Self-managing Schools. Doctoral Thesis, Unpublished. Melbourne: University of Melbourne.

Kim S 2002. Participative management and job satisfaction: Lessons for management leadership. Public Administration Review, 62(2): 231-241.

Lau CM, Lim EW 2002. The intervening effects of participation on the relationship between procedural justice and managerial performance. The British Accounting Review, 34(1).

Lichtenstein A 2000. Participatory management: A critical look. Journal of Library Administration, 31(1): 37.

Lienhart AMC, Willert HJ 2002. Involving stakeholders in resolving school violence. NASSP Bulletin, 86 (631), 32-43.

Mabaso T, Themane J 2002. Stakeholders' participation in school governanance in South Africa. Perspectives in Education, 20(3): 111-116.

Marzano RJ 2003. What Works in Schools: Translating Research into Action. Alexandria, Virginia USA: Association for Supervision and Curriculum Development.

Ming LI 2004. Workers' participation in management and firm performance: Evidence from large and mediumsized Chinese industrial enterprises. Review of Radical Political Economics, 36(3).

Mncube V 2007. Social justice, policy and parents' understanding of their voice in school governing bodies in South Africa. Journal of Educational Administration and History, 39: 129-143.

Mosoge MJ, Van der Westhuizen PC 1998. School-based management: Implications for the new roles of principals and teachers. Koers, 63(1): 73-87.

Ospina S, Yaroni A 2003. Understanding cooperative behavior in labor management cooperation: A theorybuilding exercise. Public Administration Review, 63 (4): $455-469$.

Owens RG 2001. Organizational Behavior in Education: Instructional Leadership and School Reform. $7^{\text {th }}$ Edition . Allyn and Bacon, Boston, MA.

Pagano RR 1998. Understanding Statistics in the Behavioural Sciences. $5^{\text {th }}$ Edition. Pacific Grove: Brooks/Cole Publishing Company.

Parish R, Aquila F 1996. Cultural ways of working and believing in school: Preserving the way things are. Phi Delta. Kappan, 78(4): 298-305.

Rhoades L, Eisenberger R 2002. Perceived organizational 
support: A review of the literature. Journal of Applied Psychology, 87 (4): 698-714.

Robert C 2000. Empowerment and continuous improvement in the United States, Mexico, Poland, and India: Predicting fit on the basis of the dimensions of power distance and individualism. Journal of Applied Psychology, 85(5): 643-658.

RSA (Republic of South Africa) 1996. South African Schools Act, Act 84 of 1996. Pretoria: Government Printer.

Sabo DJ, Barnes K, Hoy WK 1996. Organisational health and decisions participation: An empirical analysis of healthy interpersonal dynamics and teacher participation. Journal of School Leadership, 6: 576599.

Saunders MNK, Thornhill A 2003. Organizational justice, trust and the management of change. Personnel Review, 32(3): 360-375.

Shagoli R, Hussin S, Siraj S, Naimie Z, Assadzadeh F, Al-Hejaili H 2010. Investigation on participatory management and identify the constraints. Procedia Social and Behavioural Sciences, 2: 378-382.

Siegall M, Worth C 2001. The impacts of trust and control on faculty reactions to merit pay. Personnel Review, 30(6): 646-656

Sooksomchitra P 2004. Reforming the System of School Administration in Thailand: Facing the Challenges of the 21 st Century. PhD Thesis, Unpublished. University of Newcastle, Callgahan, NSW.

Spence-Laschinger H, Finegan JE 2004. Empowerment, Interactional Justice, Trust and Respect: A Nursing Recruitment and Retention Strategy. Academy of Management Proceedings p C1.

Spilman CE 1996. Transforming an urban school. Educational Leadership, 53(4): 34-39.
Tarter CJ, Hoy WK 1998. Towards a contingency theory of decision making. Journal of Educational Administration, 36(3): 212-228.

Tarter CJ, Bliss J, Hoy WK 1989. School characteristics and faculty trust in secondary schools. Educational Administration Quarterly, 25(3): 294-308.

Tarter CJ, Sabo D, Hoy WK 1995. Middle school climate, faculty trust and effectiveness: A path analysis. Journal of Research and Development in Education, 29(1): 41-49.

Tschannen-Moran M 2001. Collaboration and the need for trust. Journal of Educational Administration, 39(4): 308-331.

Tschannen-Moran M, Hoy WK 1998. Trust in schools: A conceptual and empirical analysis. Journal of Educational Administration, 36(4): 334-352.

Unline C, Miller D, Tschannen-Moran M 1998. Underlying dimensions of school effectiveness. Educational Administration Quarterly, 34: 462-483.

Van Wyk N 2004. School Governing Bodies: The experiences of South African Educators. South African Journal of Education, 24: 49-54.

Walker A, Dimmock C 2000. Mapping the way ahead: Leading educational leadership into the globalised world. School Leadership and Management, 20(2): 227-233.

Waters T, Marzano RJ, McNulty B 2003. Balanced Leadership: What 30 Years of Research Tells Us About the Effect of Leadership on Student Achievement. Denver, CO: Mid-Continent Regional Education Laboratory.

Wong EOW 2003. Leadership style for school-based management in Hong Kong. The International Journal of Educational Management, 17(6): 243247. 